\title{
ISOLASI METABOLIT SEKUNDER DAN UJI AKTIVITAS ANTIBAKTERI DAN ANTIOKSIDAN EKSTRAK METANOL KULIT BATANG MERANTI BUAYA (Shorea uliginosa Foxw)
}

\author{
Enda Mora $^{1^{*}}$, Rotua Serevina Br.Gultom ${ }^{1}$, Fella Eka Putri ${ }^{1}$ \\ ${ }^{1}$ Sekolah Tinggi Ilmu Farmasi Riau, Jl.Kamboja Simpang Baru Panam \\ 1Email: bangendaapt@gmail.com
}

\begin{abstract}
ABSTRAK
Telah dilakukan penelitian isolasi metabolit sekunder, uji aktivitas antibakteri dan antioksidan dari ekstrak metanol kulit batang meranti buaya (Shorea uliginosa Foxw). Ekstraksi dilakukan dengan metode maserasi menggunakan pelarut methanol. Isolasi metabolit sekunder dari ekstrak metanol dilakukan dengan menggunakan kromatografi kolom dengan metoda bergradien (Step Gradient Polarity). Hasil isolasi yang diperoleh berupa senyawa murni yang diberi label RS5 sebanyak $6 \mathrm{mg}$ dengan titik leleh $240-242{ }^{\circ} \mathrm{C}$. Berdasarkan analisis spektroskopi UV, spektroskopi IR, dan pemeriksaan fitokimia dengan menggunakan pereaksi Liebermann-Bourchard menghasilkan warna merah bata dan disimpulkan senyawa RS5 adalah golongan Terpenoid. Hasil penelitian uji aktivitas antibakteri menunjukan bahwa ekstrak metanol kulit batang meranti buaya (Shorea uliginosa Foxw) memiliki daerah diameter hambat terhadap bakteri Staphylococcus aureus dan Escherichia coli pada kategori sedang hingga lemah, dan terhadap bakteri Bacillus cereus dan Salmonella typhi pada kategori kuat hingga lemah. Sedangkan hasil uji aktivitas antioksidan ekstrak metanol memiliki aktivitas antioksidan yang kuat dengan nilai $\mathrm{IC}_{50} 40.1513 \mu \mathrm{g} / \mathrm{ml}$ dan senyawa $\mathrm{RS} 5$ memiliki aktivitas antioksidan sedang dengan nilai $\mathrm{IC}_{50} 107.1968$ $\mu \mathrm{g} / \mathrm{ml}$.
\end{abstract}

Kata Kunci : Isolasi, Shorea uliginosa Foxw, ekstraks metanol, antibakteri, antioksidan

\section{PENDAHULUAN}

Penggunaan tumbuhan-tumbuhan sebagai obatobatan telah digunakan sejak turun temurun oleh masyarakat sejak zaman dahulu, sampai saat ini. Bagian dari tanaman yang dapat dimanfaat kan sebagai obat tradisional berupa bagian akar, kulit batang, kayu, daun, bunga, buah atau bijinya. Pengobatan dengan menggunakan tumbuhan obat dipercaya lebih aman karena efek toksik dan efek samping yang lebih rendah dibandingkan dengan menggunakan obat sintesis (Rustaman dkk, 2006).

Famili Dipterocarpaceae merupakan salah satu famili tumbuhan yang dapat dijumpai dihutan tropis Indonesia. Tumbuhan ini merupakan kelompok tumbuhan tingkat tinggi penghuni hutan tropis yang tersebar disebagian wilayah Indonesia terutama hutan Kalimantan dan Sumatera. Salah satu tumbuhan yang bekhasiat sebagai obat adalah jenis tumbuhan Shorea (Ismarti, 2011). Pada bagian batang, daun, dan biji tumbuhan Shorea diduga mengandung metabolit sekunder yang berfungsi sebagai antioksidan, antibakteri, antifungi dan sitotoksik( Hakim, 2002). Beberapa spesies dari genus Shorea adalah penghasil buah tengkawang yang merupakan komoditi ekspor dimana kulit kayunya mengeluarkan getah damar yang dapat digunakan untuk berbagai keperluan, seperti dalam industri obat-obatan dan kosmetik (Saroyobudiono, 2008; Hakim dkk, 2007).

Uji senyawa oligostilbenoid dari ekstrak metanol kulit batang Shorea gibbosa, aktif sebagai anti kanker yang merupakan metabolit sekunder dari golongan fenolik (Saroyobudiono dkk, 2008), pengujian sitotoksik dari keempat senyawa oligoresveratrol yaitu Vatikanol A, $\propto-$ Viniferin,
Vanikanol B, dan Isohopeafenol hasil isolasi ekstrak aseton kulit batang Shorea assamica Dyer terhadap sel murine leukemia P-388, memiliki nilai $\mathrm{IC}_{50}$ berturutturut adalah 27,0;17,5;46,4; dan 36,0 ppm (Hadi.S, $d k k$, 2009; Hakim $d k k$, 2007). Sedangkan isolasi senyawa leavifonol, Diptoindonesin A, dan Ampelopsin A dari ekstrak etil asetat kulit batang Shorea siminis menunjukkan bahwa adanya hubungan biogenesis dari ketiga senyawa tersebut yang meupakan hasil modifikasi dari $\varepsilon$-viniferin ( Aminah dkk, 2003). Dan telah dilakukan isolasi dan uji aktivitas antioksidan dari ekstrak metanol kulit batang meranti tembaga (Shorea leprosula Miq) dengan IC $_{50}$ sebesar $42,1142 \mu \mathrm{g} / \mathrm{ml}$ (Sari, 2016).

Peneitian lainnya terhadap genus Shorea, beberapa senyawa Stillbenoid diketahui memiliki aktivitas biologis seperti sitotoksik terhadap sel kanker, menghambat pelepasan histamine, antiinflamasi, antijamur dan antibakteri yang terdapat pada Shorea leprosula Miq (Chung $d k k$, 2003). Pada hasil uji didapatkan enam senyawa oligomer resveratrol dari Shorea brunnescens yaitu (-)-(c)-viniferin(1), (-)laevifonol(2), (-)-vatikanol B (3), (-)-hemsleyanol D (4), (+)-isohopeafenol (5), dan (-)-hopeafenol (6) dan uji senyawa tersebut terhadap sel murin leukemia P388 menunjukkan hanya senyawa 6 yang menunjukkan aktivitas sitotoksik yang paling kuat dengan $\mathrm{IC}_{50} \quad 5,5$ $\mu \mathrm{M}$ (Haryato dkk, 2006).

Pada tumbuhan Shorea acuminata Dyer telah diisolasi senyawa acuminatol dan oligomer resveratrol lainnya dan telah diuji aktivitasnya sebagai antioksidan dengan nilai $\mathrm{IC}_{50} 161 \mu \mathrm{g} / \mathrm{ml}$ (Norhayati $d k k, 2012$ ), Shorea leprosula Miq juga telah behasil diisolasi senyawa metabolit sekundernya dari ekstrak aseton 
kulit batang Shorea leprosula Miq dan mengandung beberapa senyawa stilbenoid serta memiliki aktivitas biologis sebagai antikanker, antihistamin dan antibakteri (Hakim, $d k k$, 2007). Uji lanjutan tehadap Shorea leposula Miq sebagai bahan antibakteri terhadap bakteri $E$. coli dari ekstrak kulit kayu meranti merah memiliki aktivitas antibakteri yang masih tergolong lemah dan sedang (Hadi,2009). Kemudian ekstrak kulit batang meranti merah Shorea almon Foxw dan Shorea negrosensis Foxw dilaporkan mampu menghambat pertumbuhan tumor (Hakim, 2002).
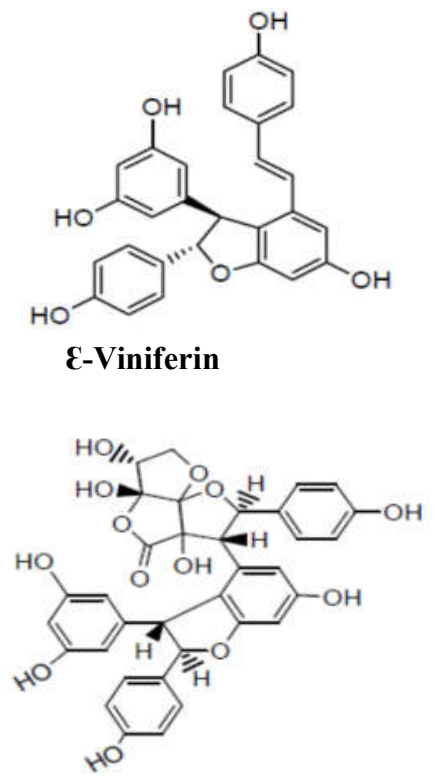

Laevifonol

Gambar 1. Kandungan Senyawa kulit batang Shorea

\section{METODOLOGI PENELITIAN}

\section{Tempat Dan Waktu Penelitian}

Penelitian ini telah dilaksanakan pada bulan September 2018 sampai bulan Februari 2019 bertempat di Laboratorium Penelitian Sekolah Tinggi Ilmu Farmasi Riau.

\section{Alat}

Alat yang digunakan dalam penelitian ini adalah sebagai berikut: seperangkat alat destilasi, satu unit rotary evaporator, lumpang, neraca analitik, kolom kromatografi, chamber, lampu UV penampak noda, vial, pipa kapiler, alat penentu titik leleh STUART melting point apparatus SMP-11, spektrofotometer UV-VIS, spektrofotometer IR, microplate readers, pipet mikro dan peralatan gelas yang umum digunakan. Cawan petri, laminary air flow (LAF). autoclave, inkubator, kertas cakram, pinset, kapas, oven, erlenmeyer, vial, beker gelas, hotplate, gunting

\section{Bahan}

Sampel yang digunakan dalam penelitian ini adalah kulit batang meranti buaya (Shorea uliginosa Foxw) sebanyak 3,5 kg yang diambil di Hutan Lindung Zamrud Kecamatan Dayun Kabupaten Siak Provinsi Riau. Bahan yang akan digunakan adalah $n$-heksana, etil asetat, metanol, asam asetat anhidrat, kloroform, kloroform amoniak, logam magnesium, norit, larutan $\mathrm{FeCl}_{3}, \mathrm{HCl} 1 \%, \mathrm{H}_{2} \mathrm{SO}_{4} 2 \mathrm{~N}$, pereaksi LiebermannBurchard, plat KLT $\mathrm{GF}_{254}$, DPPH (1,1-diphenyl-2picryl hydrazyl), vitamin $\mathrm{C}$, pereaksi Mayer, dan silika gel 60; alkohol 70\%, pelarut metanol, larutan $\mathrm{NaCl}$ fisiologis 0,9\%, Nutrient Agar (NA), bakteri uji Staphylococcus aureus, Bacillus cereus (Gram positif) dan Escherichia coli, Salmonella typhi (Gram Negatif), sebagai kontrol positif Ciprofloxacin $10 \mu \mathrm{g}$.

\section{Prosedur Penelitian}

\section{Pengambilan Sampel}

Sampel yang digunakan adalah kulit batang dari meranti buaya (Shorea uliginosa Foxw) yang diambil di Hutan Lindung Zamrud, Kecamatan Dayun Kabupaten Siak, Provinsi Riau.

\section{Identifikasi Tanaman}

Identifikasi tumbuhan meranti buaya (Shorea uliginosa Foxw) dilakukan di Balai Pendidikan dan Pelatihan Kehutanan Pekanbaru.

\section{Persiapan Sampel}

Kulit batang dari tumbuhan meranti buaya (Shorea uliginosa Foxw) terlebih dahulu dibersihkan dari kotoran yang melekat. Kemudian dikeringkan ditempat teduh selama satu bulan dan dihaluskan.

\section{Uji Pendahuluan dan Fitokimia}

Uji fitokimia dilakukan terhadap kulit batang dan ekstrak methanol meranti buaya (Shorea uliginosa Foxw).

\section{Pengolahan Sampel}

Sampel terlebih dahulu diproses dengan cara maserasi bertingkat dimana sampel pertama dimaserasi dengan pelarut $\mathrm{n}$-heksan, lalu ampasnya dimaserasi kembali dengan etil asetat, kemudian perlakuan yang sama dilakukan terhadap pelarut metanol, ampas dimaserasi dengan metanol dengan masing-masing 3 kali pengulangan selama 5 hari. Kemudian pada pelarut metanol di saring sehingga diperoleh maserat. Maserat di pekatkan dengan rotary evaporator sehingga diperoleh ekstrak metanol kulit batang meranti buaya.

\section{Pemisahan dengan Kromatografi Kolom}

Pemisahanan senyawa yang ada di dalam ekstrak dilakukan kromatografi kolom memakai silika gel 60 . Pengisian kolom dilakukan dengan membuat bubur 
silika terlebih dahulu, lalu dimasukkan ke dalam kolom dengan menggunakan corong, kemudian dielusi sampai kerapatan silika di dalam kolom maksimum. Ekstrak yang akan dipisahkan dilakukan preadsorpsi dan dimasukkan dalam kolom. Kemudian dielusi dengan sistem gradien menggunakan pelarut n-heksan, etil asetat dan kemudian dengan metanol, memakai gaya gravitasi. Hasil pemisahan ditampung dalam vial dan diberi nomor, dan dikelompokkan berdasarkan hasil KLT dan Rf yang sama digabungkan menjadi satu fraksi. Vial-vial yang dihasilkan dari kromatografi kolom ini sebanyak 430 vial.

\section{Rekristalisasi}

Proses rekristalisasi dilakukan dengan melarutkan zat dengan pelarut yang mudah melarutkan dengan sesedikit mungkin kemudian tambahkan secara bertahap pelarut dimana zat sukar melarutkannya. Saat penambahan pelarut akan berubah dan zat dapat mencapai titik jenuh. Pada kondisi ini, biarkan larutan kembali jenuh sehingga proses pembentukan kristal berjalan secara perlahan.

Senyawa yang dipilih yaitu pada fraksi 5 direkristalisasi menggunakan sedikit pelarut etil asetat yang melarutkannya kemudian di tambahkan banyak pelarut yang tidak melarutkannya yaitu $n$-heksan. Proses rekristalisasi ini menghasilkan senyawa murni yang diberi label RS5 sebanyak $6 \mathrm{mg}$ yang berupa padatan amorf berwarna putih kecoklatan.

\section{Penentuan titik leleh}

Penentuan titik leleh dilakukan dengan menggunakan alat penentuan titik leleh Fisher Jhones. Pembacaan titik leleh dimulai saat kristal mulai meleleh sampai habis meleleh semuanya. Jika selisih harga titik lelehnya kecil atau sama dengan $2^{0} \mathrm{C}$ maka senyawa tersebut sudah murni.

\section{Identifikasi}

Senyawa murni hasil isolasi yang didapat dilakukan karakterisasi dari senyawa tersebut. Pemeriksaan tersebut meliputi : pemeriksaan Organoleptis, pemeriksaan sifat kimia, sifat fisika, dan karakterisasi dengan spectrum UVdan IR.

\section{Uji Aktivitas Antioksidan Dengan Metoda DPPH}

\section{Pembuatan pereaksi DPPH}

Kristal DPPH ditimbang sebanyak $2 \mathrm{mg}$ kemudian dilarutkan dalam $2 \mathrm{ml}$ metanol sehingga konsentrasinya 1000 ppm.

\section{Persiapan sampel}

Sampel diambil sebanyak $2 \mathrm{mg}$ dilarutkan dalam $2 \mathrm{ml}$ metanol sehingga konsentrasi sampel menjadi 1000 $\mu \mathrm{g} / \mathrm{ml}$. Pengujian dilakukan dalam 6 seri konsentrasi yaitu 31,$25 ; 62,5 ; 125 ; 250 ; 500$; dan 1000 ppm dalam larutan metanol p.a. Vitamin $\mathrm{C}$ diambil $2 \mathrm{mg}$ kemudian dilarutkan dengan 0,2 $\mathrm{ml}$ metanol p.a.

\section{Pengujian aktivitas antioksidan}

Uji aktivitas antioksidan dilakukan menggunakan microplate reader two fold delution dengan metode DPPH (1,1-diphenyl-2-picryl hydrazyl) (Noorhayati, 2012) pada panjang gelombang $517 \mathrm{~nm}$. Sampel senyawa hasil isolasi sebanyak $2 \mathrm{mg}$ dilarutkan dalam $2 \mathrm{~mL}$ metanol sehinga konsentrasi sampel menjadi $1000 \mu \mathrm{g} / \mathrm{mL}$. Baris A dimasukkan sampel sebanyak $100 \mu \mathrm{L}$ (plate terdiri dari baris A-H masingmasing berjumlah 12 sumur). Sebanyak $50 \mu \mathrm{L}$ metanol dimasukkan pada masing-masing sumur pada baris BF. Baris A dipipet sebanyak $50 \mu \mathrm{L}$ dan dimasukkan kebaris $\mathrm{B}$, baris $\mathrm{B}$ dipipet $50 \mu \mathrm{L}$ baris $\mathrm{C}$ dan dilakukan sampai kebaris $\mathrm{F}$, baris $\mathrm{F}$ dipipet $50 \mu \mathrm{L}$ dan dibuang, sehingga diperoleh masing-masing konsentrasi 1000 , $500,250,125,62,5$ dan 31,25 $\mu \mathrm{g} / \mathrm{mL}$. Sedangkan baris $\mathrm{G}-\mathrm{H}$ diisi dengan $\mathrm{MeOH} 50 \mu \mathrm{l}$. Baris A-G ditambahkan DPPH sebanyak $80 \mu \mathrm{L}$ dengan konsentrasi $80 \mu \mathrm{g} / \mathrm{mL}$, kemudian diinkubasi selama 30 menit. Aktivitas penangkapan radikal diukur sebagai penurunan absorbansi DPPH dengan microplate reader. Kontrol positif yang digunakan sebagai pembanding yaitu asam askorbat dengan konsentrasi 100, 50, 25, 12,5, 6,25, $3,125 \mu \mathrm{g} / \mathrm{mL}$.

\section{Uji Aktivitas Antibakteri}

\section{Sterilisasi Alat dan Bahan}

Alat-alat yang terbuat dari gelas (tabung reaksi, cawan Petri, vial) ditutup mulutnya dengan kapas yang dibungkus dengan kain kasa kemudian dimasukkan kedalam oven pada suhu $160^{\circ} \mathrm{C}$ selama \pm 2 jam. Medium nutrient agar dan aquadest didalam erlenmeyer yang telah ditutup mulutnya dengan kapas disterilkan menggunakan autoclave pada suhu $121^{\circ} \mathrm{C}$ selama 15 menit. Pinset, spatel dan jarum Ose sterilkan dengan api langsung setiap kali akan digunakan. Meja aseptis dibersihkan dari debu lalu disemprot dengan alkohol 70\% dan dibiarkan selama 15 menit sebelum digunakan.

\section{Pembuatan Media Nutrient Agar}

Disiapkan sebanyak 10 gram medium agar dan disiapkan $500 \mathrm{ml}$ aquadest, Nutrient Agar yang telah ditimbang dimasukkan kedalam erlenmeyer kemudian ditambah aquadest sampai $500 \mathrm{ml}$, lalu dipanaskan diatas hotplate sambil diaduk hingga larutan bening kekuningan kemudian disumbat dengan kapas lalu disterilkan didalam autoklaf pada suhu $121^{\circ} \mathrm{C}$ selama 15 menit.

\section{Peremajaan bakteri}

Media NA steril yang telah dipanaskan dibiarkan beberapa menit hingga temperature sekitar 
$40-50^{\circ} \mathrm{C}$, lalu dimasukkan kedalam tabung reaksi steril dan dimiringkan dibiarkan mengeras, kemudian ditambahkan satu atau dua Ose bakteri menggunakan jarum Ose steril dari stok murni dan digoreskan. Selanjutnya diinkubasi dalam inkubator pada suhu $37^{\circ} \mathrm{C}$ selama 24 jam. Perlakuan yang sama dilakukan pada setiap jenis bakteri uji.

\section{Pembuatan Suspensi Bakteri Uji}

Bakteri uji yang diremajakan digoreskan sebanyak 3-4 goresan, kemudian dimasukkan kedalam tabung reaksi yang sudah berisi $\mathrm{NaCl}$ Fisiologis $0,9 \%$ $\mathrm{b} / \mathrm{v}$, kemudian dihomogenkan dengan vorteks. Setelah itu diukur transmitan bakteri dengan menggunakan alat spektofotometer UV-VIS sehingga diperoleh suspensi dengan transmitan $25 \%$ pada panjang gelombang 580 nm.

\section{Penyiapan Konsentrasi Ekstrak}

Ekstrak metanol kulit batang meranti buaya ditimbang seberat 0,25 gram, kemudian dilarutkan dalam $1 \mathrm{ml}$ metanol, sehingga didapat konsentrasi 25\% $\mathrm{b} / \mathrm{v}$ dan dibuat konsentrasi pengenceran ekstrak dari $20 \%, 15 \%, 10 \%$ dan $5 \%$.

\section{Pengujian Uji Aktivitas Antibakteri}

Sebanyak 0,3 $\mathrm{ml}$ suspensi mikroba uji dimasukkan ke dalam cawan Petri kemudian masukkan 10-15 ml medium NA lalu di homogenkan. Setelah media memadat diletakkan kertas cakram steril yang telah ditetesi larutan uji sebanyak $10 \mu$ l. sebagai kontrol negatif digunakan pelarut metanol yang telah ditetesi di atas cakram steril. Sebagai kontrol positif digunakan Ciprofloxacin $10 \mu \mathrm{g}$ yang langsung dapat digunakan. Lalu inkubasi selama 18-24 jam pada suhu $37^{\circ} \mathrm{C}$. Amati zona hambat sekitar kertas cakram pada tiap tiap cawan Petri, diukur diameter daerah hambatan dengan jangka sorong dan percobaan di ulang sebanyak 3 kali pengulangan.

\section{Analisa Data}

Teknik pengolahan data yang digunakan untuk uji aktivitas antibakteri yaitu dengan cara mengukur diameter daerah bening sekitar kertas cakram yang didapat dari masing-masing konsentrasi ekstrak menggunakan jangka sorong. Lalu dihitung rata-rata zona hambatannya.

\section{HASIL DAN PEMBAHASAN}

\section{HASIL}

Berdasarkan penelitian yang telah dilakukan dari $5 \mathrm{~kg}$ kulit batang meranti buaya maka didapatkan hasil penelitian yaitu , sampel kering sebanyak $2,5 \mathrm{~kg}$ (43,7\%); ekstrak kental metanol sebanyak 170, 651 gram $(4,875 \%)$. Hasil uji fitokimia kulit batang merati buaya (Shorea uliginosa Foxw) menunjukkan positif mengandung senyawa flavonoid, terpenoid dan saponin, sedangkan hasil uji fitokimia terhadap ekstrak kental metanol kulit batang meranti buaya menunjukkan positif mengandung senyawa terpenoid dan saponin.

Hasil pemurnian fraksi menghasilkan suatu senyawa dengan satu noktah tunggal pada plat KLT dan diberi label RS5. Pemeriksaan sifat kimia senyawa murni RS5 diperoleh sebanyak $6 \mathrm{mg}$, berbentuk amorf, bewarna putih kecoklatan, larut dalam methanol dan etil asetat, sangat sukar larut dalam n- heksan, dengan titik leleh 240-242 ${ }^{\circ} \mathrm{C}$, dengan pereaksi kimia menunjukkan warna merah terhadap pereaksi Lieberman-Burchard yang menunjukkan hasil positif sebagai senyawa terpenoid. Hasil pengukuran spektrum ultraviolet senyawa murni RS5 memberikan dua puncak serapan dengan munculnya serapan maksimum 0.369 dengan panjang gelombang maksimum $284 \mathrm{~nm}$ dan 0.212 dengan panjang gelombang $259 \mathrm{~nm}$, spektrum inframerah senyawa murni RS5 terlihat adanya gugus $\mathrm{O}-\mathrm{H}$ pada bilangan gelombang $3422.83 \mathrm{~cm}^{-1}$. Bilangan gelombang 3284.91 $\mathrm{cm}^{-1}$ yaitu gugus $\mathrm{CH}$ aromatik. Bilangan gelombang $2849.95 \mathrm{~cm}^{-1}$ dan bilangan $2917.46 \mathrm{~cm}^{-1}$ menandakan adanya gugus $\mathrm{CH}$ alifatik.

Aktivitas antibakteri ekstrak metanol kulit batang meranti buaya (Shorea uliginosa Foxw) pada konsentrasi $25 \%, 20 \%, 15 \%, 10 \%$ dan 5\% memberikan hasil positif terhadap bakteri uji. Hal ini dibuktikan dengan adanya zona hambatan seperti yang terlihat pada gambar dibawah ini.

Hasil uji aktivitas antioksidan untuk ekstrak metanol kulit batang meranti buaya (Shorea uliginosa Foxw) di dapatkan $\mathrm{IC}_{50} 40.1513 \mu \mathrm{g} / \mathrm{ml}$ menunjukkan sebagai antioksidan kuat, sedangkan untuk senyawa murni RS5 didapatkan nilai IC $_{50} 107.1968 \mu \mathrm{g} / \mathrm{ml}$ menunjukkan antioksidan sedang.
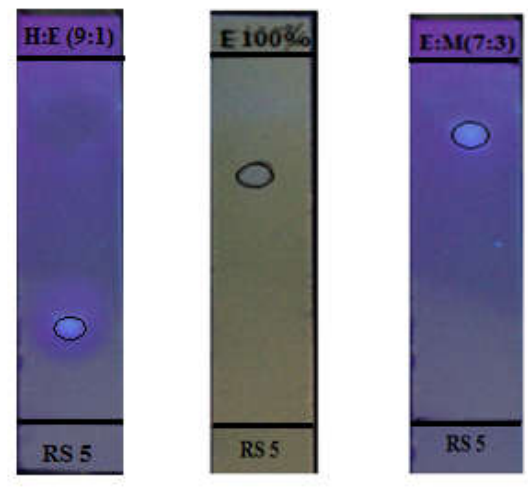

Gambar 2. Profil Kromatografi Lapis Tipis Senyawa RS5 dengan Tiga Eluen 
Jurnal Penelitian Farmasi Indonesia 8(2), Desember 2019 ISSN 2302-187X $e$-ISSN 2656-3614

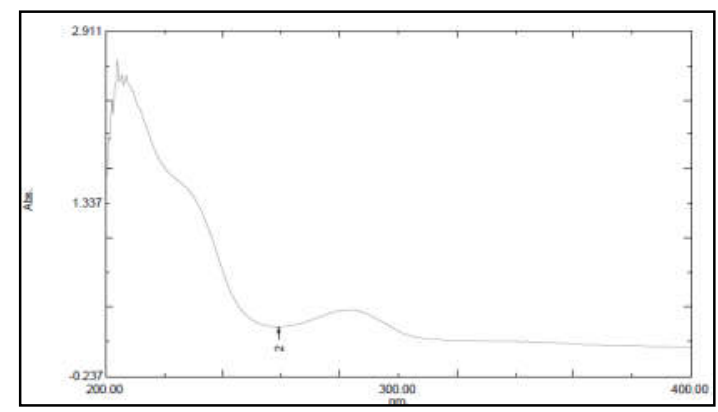

Gambar 3. Spektrum UV Senyawa RS5 Pada Daerah Panjang Gelombang 200-400 nm.

Tabel 1. Diameter hambat ekstraks methanol meranti buaya

\begin{tabular}{|c|c|c|c|c|}
\hline \multirow{2}{*}{$\begin{array}{l}\text { Kons } \\
\text { en } \\
\text { trasi }\end{array}$} & \multicolumn{4}{|c|}{ Rata-rata Diameter hambat } \\
\hline & $\begin{array}{l}\text { Staphylo } \\
\text { coc cus } \\
\text { aureus }\end{array}$ & $\begin{array}{l}\text { Bacillus } \\
\text { cereus }\end{array}$ & $\begin{array}{l}\text { Salmonell } \\
\text { a typhi }\end{array}$ & $\begin{array}{l}\text { Escherich } \\
\text { ia coli }\end{array}$ \\
\hline $\begin{array}{c}\text { Ekstrak } \\
5 \%\end{array}$ & $7,30 \pm 0,26$ & $8,27 \pm 0,46$ & $7,03 \pm 0,65$ & $7,37 \pm 0,40$ \\
\hline $\begin{array}{c}\text { Ekstrak } \\
10 \%\end{array}$ & $10,10 \pm 0,30$ & $9,80 \pm 0,53$ & $9,93 \pm 0,31$ & $9,77 \pm 0,25$ \\
\hline $\begin{array}{c}\text { Ekstrak } \\
15 \%\end{array}$ & $11,83 \pm 0,55$ & $10,97 \pm 0,51$ & $11,80 \pm 0,20$ & $11,20 \pm 0,35$ \\
\hline $\begin{array}{c}\text { Ekstrak } \\
20 \%\end{array}$ & $13,10 \pm 0,56$ & $13,03 \pm 1,80$ & $12,73 \pm 0,70$ & $12,23 \pm 0,32$ \\
\hline $\begin{array}{c}\text { Ekstrak } \\
25 \%\end{array}$ & $14,20 \pm 0,95$ & $16,30 \pm 0,66$ & $15,13 \pm 0,45$ & $12,83 \pm 0,15$ \\
\hline
\end{tabular}

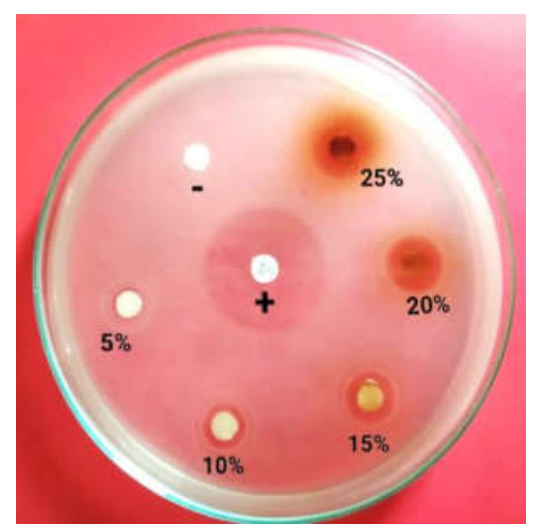

Gambar 5. Daya hambat ekstrak methanol meranti buaya terhadap bakteri Staphylococcus aureus

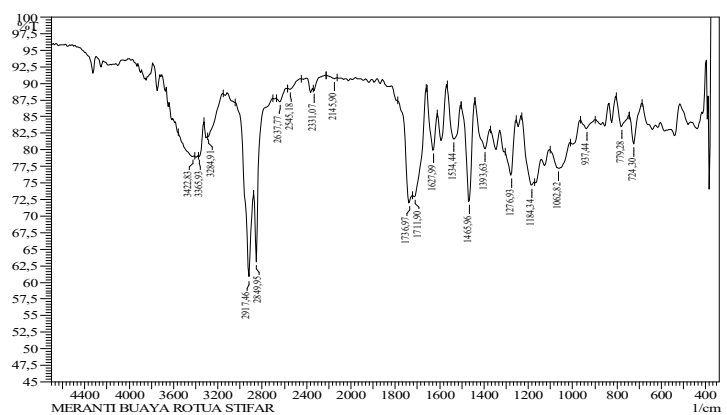

Gambar 4. Spektrum IR senyawa RS 5

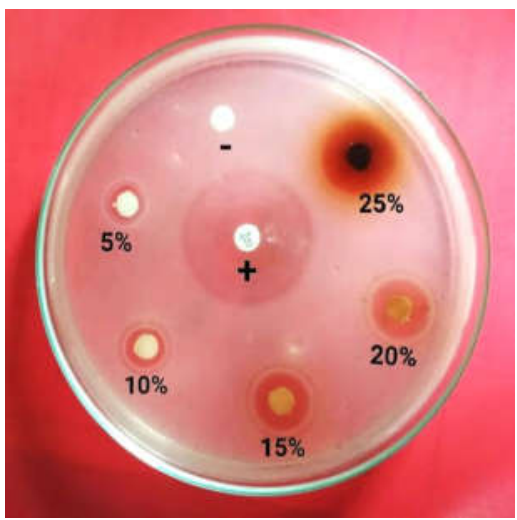

Gambar 6. Daya hambat ekstrak methanol meranti buaya terhadap bakteri Bacillus cereus

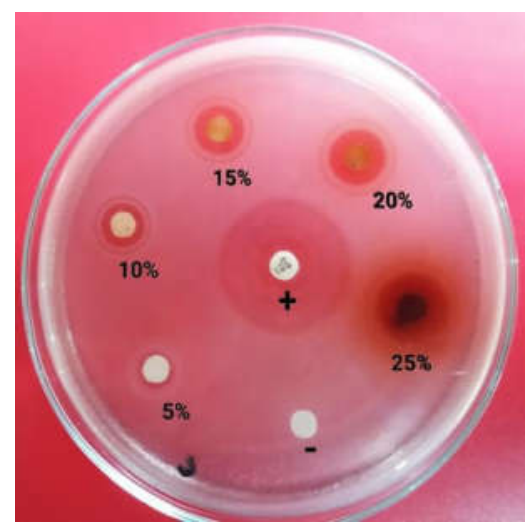

Gambar 7. Daya hambat ekstrak methanol meranti buaya terhadap bakteri Salmonella typhii. 


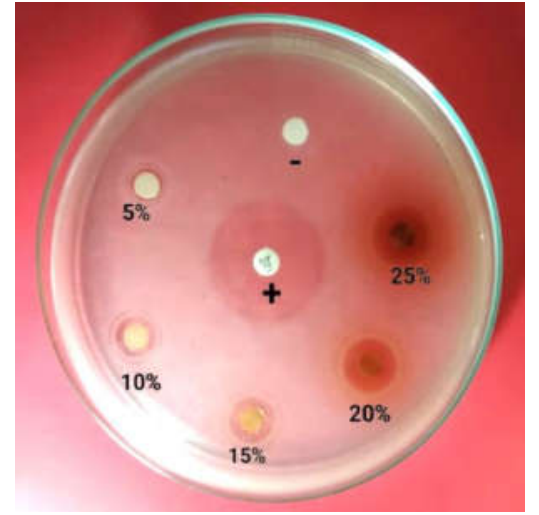

Gambar 8. Daya hambat ekstrak methanol meranti buaya terhadap bakteri Escherichia coli

Tabel 2. Hasil Uji Aktivitas Antioksidan Ekstrak Metanol Kulit Batang Meranti Buaya (Shorea uliginosa Foxw)

\begin{tabular}{|c|c|c|c|c|c|c|c|c|}
\hline Kons & Ln & \multicolumn{3}{|c|}{ Absorban } & \multirow{2}{*}{$\begin{array}{c}\text { Abs } \\
\text { or } \\
\text { ban } \\
\text { rata- } \\
\text { rata }\end{array}$} & \multirow{2}{*}{$\begin{array}{c}\text { Absor } \\
\text { ban } \\
\text { samp } \\
\text { el }\end{array}$} & \multirow{2}{*}{$\begin{array}{c}\% \\
\text { inhi } \\
\text { bisi }\end{array}$} & \multirow{2}{*}{$\begin{array}{c}\mathrm{IC}_{50} \\
(\mu \mathrm{g} / \mathrm{m} \\
\mathrm{L})\end{array}$} \\
\hline $\begin{array}{l}\mu \mathrm{g} / \\
\mathrm{mL}\end{array}$ & & 1 & 2 & 3 & & & & \\
\hline $\begin{array}{c}100 \\
0\end{array}$ & 6.908 & $\begin{array}{c}0.11 \\
3\end{array}$ & $\begin{array}{c}0.11 \\
3\end{array}$ & $\begin{array}{c}0.11 \\
2\end{array}$ & 0.11 & 0.038 & 90.05 & \multirow{6}{*}{$\begin{array}{l}40.15 \\
1\end{array}$} \\
\hline 500 & 6.215 & $\begin{array}{c}0.13 \\
1\end{array}$ & $\begin{array}{c}0.13 \\
2\end{array}$ & $\begin{array}{c}0.13 \\
1\end{array}$ & 0.13 & 0.057 & 85.16 & \\
\hline 250 & 5.521 & $\begin{array}{c}0.16 \\
1\end{array}$ & $\begin{array}{c}0.16 \\
5\end{array}$ & $\begin{array}{c}0.16 \\
6\end{array}$ & 0.16 & 0.089 & 76.61 & \\
\hline 125 & 4.828 & $\begin{array}{c}0.19 \\
2\end{array}$ & $\begin{array}{c}0.19 \\
5\end{array}$ & $\begin{array}{c}0.19 \\
5\end{array}$ & 0.19 & 0.119 & 68.75 & \\
\hline 62,5 & 4.135 & $\begin{array}{c}0.24 \\
2\end{array}$ & $\begin{array}{c}0.24 \\
2\end{array}$ & $\begin{array}{c}0.24 \\
9\end{array}$ & 0.24 & 0.169 & 55.66 & \\
\hline $\begin{array}{c}31,2 \\
5\end{array}$ & 3.442 & $\begin{array}{c}0.28 \\
9\end{array}$ & $\begin{array}{c}0.28 \\
9\end{array}$ & $\begin{array}{c}0.28 \\
9\end{array}$ & 0.29 & 0.214 & 43.88 & \\
\hline
\end{tabular}

Tabel 3. Hasil Uji Aktivitas Antioksidan senyawa RS5

\begin{tabular}{|c|c|c|c|c|c|c|c|c|}
\hline \multirow{2}{*}{$\begin{array}{l}\text { Konse } \\
\mathrm{n} \text { trasi } \\
\mu \mathrm{g} / \mathrm{m} \\
\mathrm{L}\end{array}$} & \multirow{2}{*}{$\begin{array}{c}\text { Ln } \\
\text { konse } \\
\mathrm{n} \text { trasi }\end{array}$} & \multicolumn{3}{|c|}{ Absorban } & \multirow{2}{*}{$\begin{array}{c}\text { Abs } \\
\text { or } \\
\text { ban } \\
\text { rata- } \\
\text { rata }\end{array}$} & \multirow{2}{*}{$\begin{array}{c}\text { Absor } \\
\text { ban } \\
\text { samp } \\
\text { el }\end{array}$} & \multirow{2}{*}{$\begin{array}{c}\% \% \\
\text { inhi } \\
\text { bisi }\end{array}$} & \multirow{2}{*}{$\begin{array}{c}\mathrm{IC}_{50} \\
(\mu \mathrm{g} / \mathrm{m} \\
\mathrm{L})\end{array}$} \\
\hline & & 1 & 2 & 3 & & & & \\
\hline 1000 & 6.908 & $\begin{array}{c}0.11 \\
3\end{array}$ & $\begin{array}{c}0.11 \\
5\end{array}$ & 0.13 & 0.12 & 0.045 & 88.3 & \multirow{6}{*}{$\begin{array}{c}107.1 \\
968\end{array}$} \\
\hline 500 & 6.215 & $\begin{array}{c}0.15 \\
4\end{array}$ & $\begin{array}{c}0.15 \\
3\end{array}$ & $\begin{array}{c}0.15 \\
8\end{array}$ & 0.16 & 0.08 & 79.97 & \\
\hline 250 & 5.521 & $\begin{array}{c}0.19 \\
6\end{array}$ & $\begin{array}{c}0.18 \\
7\end{array}$ & $\begin{array}{c}0.19 \\
5\end{array}$ & 0.19 & 0.118 & 69.1 & \\
\hline 125 & 4.828 & $\begin{array}{c}0.23 \\
9\end{array}$ & $\begin{array}{c}0.23 \\
2\end{array}$ & $\begin{array}{c}0.23 \\
2\end{array}$ & 0.23 & 0.16 & 58.19 & \\
\hline 62,5 & 4.135 & $\begin{array}{c}0.32 \\
4\end{array}$ & 0.32 & $\begin{array}{c}0.29 \\
4\end{array}$ & 0.31 & 0.238 & 37.68 & \\
\hline 31,25 & 3.442 & $\begin{array}{c}0.36 \\
8\end{array}$ & 0.36 & $\begin{array}{c}0.36 \\
4\end{array}$ & 0.36 & 0.289 & 24.24 & \\
\hline
\end{tabular}

\section{Pembahasan}

Sampel dimaserasi secara langsung mulai dari pelarut non polar, semi polar dan polar masing-masing selama 5 hari dengan 3 kali pengulangan. Pemakaian pelarut n-heksan, etil asetat dan metanol sebagai cairan penyari bertujuan memisahkan senyawa berdasarkan tingkat kepolarannya. Maserat metanol yang diperoleh dari hasil proses maserasi dipekatkan dengan rotary evaporator pada suhu $60-65^{\circ} \mathrm{C}$ dengan bantuan pompa vakum atau rotary evaporator. Penggunaan rotary evaporator untuk memisahkan pelarut yang terdapat pada ekstrak sehingga didapatkan ekstrak kental. Tujuannya adalah agar komponen fitokimia yang terdapat dalam ekstrak tidak mengalami kerusakan akibat pemanasan yang berlebihan. Ekstrak kental metanol yang diperoleh seluruhnya adalah $170,651 \mathrm{gr}$ gram dengan rendemen $(4,875 \%)$. Hasil skrining fitokimia ekstrak metanol kulit batang meranti buaya (Shorea uliginosa Foxw) mengandung terpenoid dan saponin.

Isolasi senyawa metabolit sekunder dilakukan dengan menggunakan metode kromatografi kolom dengan mengunakan ekstrak metanol sebanyak 4 gram pada kolom dengan diameter $1,5 \mathrm{~cm}$ dan panjang $30 \mathrm{~cm}$ memakai silica gel $60 \mathrm{GF}_{254}(70-230$ mesh) dengan sistem elusi yang digunakan adalah dengan kepolaran bertingkat atau Step Gradient Polarity (SGP). Hasil pemisahan dengan kromatografi kolom yaitu sebanyak 430 vial, selanjutnya dimonitor dengan KLT, dengan cara diambil setiap jarak 5 vial, kemudian masing-masing fraksi ditotolkan pada plat yang telah diberi nomor sesuai dengan nomor vial. Plat KLT yang telah ditotol dielusi dengan eluen yang sesuai dan untuk melihat noktah yang dihasilkan dapat diamati dibawah lampu UV $\lambda_{254} \mathrm{~nm}$ dan UV $\lambda_{366} \mathrm{~nm}$. Selanjutnya ditentukan Rf dari masing-masing noktah, vial yang memiliki Rf yang sama dapat digabung menjadi satu fraksi sehingga didapatkan fraksi gabungan dan diberi label.

Dari hasil isolasi ekstrak metanol kulit batang meranti buaya (Shorea uliginosa Foxw) hasil KLT fraksi 5 menunjukkan 3 pola noda yang terbentuk dan pada dasar vial terdapat amorf yang bewarna kuning kecoklatan. Fraksi 5 ini dimurnikan dengan cara rekristalisasi Proses rekristalisasi ini diulang beberapa kali sampai didapatkan senyawa murni dan dimonitor kembali dengan KLT. Proses rekristalisasi ini menghasilkan senyawa murni yang diberi label RS5 sebanyak $6 \mathrm{mg}$ yang berupa amorf bewarna kuning kecoklatan. Karakterisasi yang dilakukan, senyawa ini larut dalam methanol, etil asetat, dan sangat sukar larut dalam n-heksan. Sedangkan uji titik leleh menggunakan alat STUART Melting point apparatus diperoleh nilai titik leleh $240-242^{\circ} \mathrm{C}$, dimana suatu senyawa dikatakan murni salah satunya apabila selisih titik lelehnya kecil atau sama dengan 
$2^{\circ} \mathrm{C}$, maka senyawa ini bisa dikatakan murni. Pengujian fitokimia senyawa RS5 dilakukan dengan reagen Liebermann-Burchard terbentuk warna merah bata yang berarti positif golongan terpenoid.

Selanjutnya pada senyawa RS5 dilakukan identifikasi senyawa menggunakan Spektrofotometri UV dan IR. Pada spektrum IR pita serapan menunjukkan adanya bilangan gelombang yang melebar pada bilangan gelombang $3422.83 \mathrm{~cm}^{-1}$ yang khas untuk gugus hidroksil $(-\mathrm{OH})$. Bilangan gelombang $3284.91 \mathrm{~cm}^{-1}$ yaitu gugus $\mathrm{CH}$ aromatik. Pada bilangan gelombang $2849.95 \mathrm{~cm}^{-1}$ dan bilangan $2917.46 \mathrm{~cm}^{-1}$ menandakan adanya gugus $\mathrm{CH}$ alifatik. Pada $1276.93 \mathrm{~cm}^{-1}$ menunjukkan adanya ikatan CO,dan pada bilangan gelombang $1736.97 \mathrm{~cm}^{-1}$ menandakan adanya gugus $\mathrm{C}=\mathrm{O}$. Munculnya ulur $\mathrm{C}-\mathrm{H}$ alifatik pada bilangan gelombang $2917.46 \mathrm{~cm}^{-1}$ memberikan petunjuk kemungkinan adanya gugus metil $\left(\mathrm{CH}_{3}\right)$ dan metilena $\left(\mathrm{CH}_{2}\right)$. Data ini juga diperkuat dengan adanya vibrasi tekuk $\mathrm{C}-\mathrm{H}$ pada panjang gelombang $1393.63 \mathrm{~cm}^{-1}$ dan $1465.96 \mathrm{~cm}^{-1}$ yang mengindikasikan adanya gugus geminal dimetil $\left(\mathrm{C}\left(\mathrm{CH}_{3}\right) 2\right)$ yang merupakan ciri khas senyawa terpenoid.

Pengujian aktivitas antibakteri ekstrak metanol kulit batang meranti buaya (Shorea uliginosa Foxw) dibuat pengenceran dengan konsentrasi 25\%, 20\%, $15 \%, 10 \%$ dan $5 \%$. Pemilihan variasi konsentrasi tersebut agar didapat konsentrasi sampel uji yang masing-masing memberikan kekuatan daya hambat yang berbeda dan mendekati daya hambat minimum. Pengujian ini dilakukan pengulangan sebanyak 3 kaliyang bertujuan untuk perbandingan data yang didapat dan untuk hasil perbandingan agar lebih akurat. Cara pengujian dilakukan dengan metoda diffusi yaitu dengan meneteskan sampel pada kertas cakram sedikit demi sedikit sebanyak $10 \mu$, lalu dibiarkan hingga kering, kemudian diletakkan pada piringan bakteri uji yang telah mengeras lalu diamati daya hambatnya sebagai antibakteri. Daya hambat yang diberikan oleh ekstraks adalah berbeda dari empat bakteri tersebut, disebabkan karena adanya perbedaan kepekaan bakteri Gram positif dan Gram negative. Struktur dinding sel bakteri Gram positif mengandung banyak lapisan peptidoglikan yang membentuk struktur tebal dan kaku, serta asam teikoat yang mengandung alkohol dan fosfat. Dinding sel bakteri Gram negatif tidak mengandung asam teikoat, karena hanya mengandung sejumlah kecil peptidoglikan dan tersusun dari beberapa polisakarida sehingga rentan terhadap kerusakan mekanik maupun kimia (Pratiwi, 2008).

Uji aktivitas antioksidan dilakukan
pengukuran peredaman radikal bebas dengan
microplate readers. Prinsipnya adalah pengukuran
besarnya absorbansi pemucatan warna larutan DPPH
oleh sampel uji setelah diinkubasi selama 30 menit.

Uji aktivitas antioksidan dilakukan oleh sampel uji setelah diinkubasi selama 30 menit.
Aktivitas antioksidan suatu ekstrak atau suatu senyawa ditunjukkan oleh adanya hambatan serapan maksimum DPPH yaitu pada panjang gelombang maksimum 517 $\mathrm{nm}$. Pada saat terjadinya reaksi dengan agen pereduksi yang berasal dari ekstrak atau senyawa uji, elektron radikal dari DPPH yang tidak berpasangan atau bersifat radikal, akan menjadi berpasangan dan akan bersifat netral atau bukan radikal (DPPH-H). Hal ini akan menyebabkan pengurangan serapan dari radikal DPPH yang diamati dengan perubahan warna larutan dari wana ungu menjadi warna terang atau kuning (Molyneux, 2004; Haryanto dan Nugroho, 2007).

Dari hasil pengujian ekstrak metanol kulit batang meranti buaya (Shorea uliginosa Foxw) didapat persen inhibisi sebesar $84.9385 \%$ pada konsentrasi $1000 \mu \mathrm{g} / \mathrm{mL}$ dengan nilai $\mathrm{IC}_{50}$ sebesar $40.1513 \mu \mathrm{g} / \mathrm{ml}$ sedangkan persen inhibisi untuk senyawa murni RS5 sebesar $82.1640 \%$ pada konsentrasi $1000 \mu \mathrm{g} / \mathrm{ml}$ dengan nilai $\mathrm{IC}_{50} 107.1968 \mu \mathrm{g} / \mathrm{ml}$. Jika dibandingkan dengan dengan nilai $\mathrm{IC}_{50}$ dari asam askorbat yang dijadikan kontrol yaitu $7.2849 \mu \mathrm{g} / \mathrm{ml}$, maka nilai $\mathrm{IC}_{50}$ dari hasil ekstrak tergolong kuat dam nilai $\mathrm{IC}_{50}$ senyawa murni RS5 tergolong sedang berdasarkan tabel penetuan nilai $\mathrm{IC}_{50}$ (Chung $d k k, 2003$ ). Hal ini diprediksi disebabkan senyawa RS5 merupakan senyawa murni hasil isolasi dari ekstrak metanol kulit batang meranti buaya (Shorea uliginosa Foxw), sedangkan ekstrak masih berupa campuran berbagai senyawa. Berbagai senyawa yang terdapat dalam ekstrak metanol tersebut ada yang memiliki aktivitas antioksidan tetapi ada pula yang tidak, namun hal ini tidak menjamin senyawa yang tekandung dalam ekstrak metanol memiliki aktivitas antioksidan yang lebih baik dari senyawa murni RS5.

\section{SIMPULAN DAN SARAN}

\section{Simpulan}

1. Hasil isolasi dari ekstrak metanol kulit batang meranti buaya (Shorea uliginosa Foxw) diperoleh diperoleh senyawa murni RS5 sebanyak $6 \mathrm{mg}$, berupa amorf bewarna putih kecoklatan dengan titik leleh $240-242^{\circ} \mathrm{C}$, dengan penambahan pereaksi Liebermann-Burchard memberikan perubahan warna merah bata,sehingga senyawa ini merupakan golongan Terpenoid.

2. Hasil uji aktivitas atibakteri Ekstrak metanol kulit batang meranti buaya (Shorea uliginosa Foxw) memiliki aktivitas sebagai antibakteri terhadap Staphylococcus aureus, Bacillus cereus, Salmonella typhi dan Escherichia coli. Aktivitas antibakteri ekstrak metanol kulit batang meranti buaya pada konsentrasi $25 \%$, $20 \%, 15 \%, 10 \%$ dan 5\% memberikan diameter hambat terhadap bakteri Staphylococcus aureus dan Escherichia coli pada kategori sedang hingga lemah. Terhadap bakteri Bacillus cereus 
Jurnal Penelitian Farmasi Indonesia 8(2), Desember 2019

ISSN 2302-187X $\quad e$-ISSN 2656-3614

dan Salmonella typhi pada kategori kuat hingga lemah.

3. Hasil uji aktivitas antioksidan pada ekstrak metanol kulit batang meranti buaya (Shorea uliginosa Foxw) menunjukkan aktivitas antioksidan yang kuat dengan nilai $\mathrm{IC}_{50}$ $40.1513 \mu \mathrm{g} / \mathrm{ml}$ dan pada senyawa murni RS5 didapatkan nilai $\quad \mathrm{IC}_{50} \quad 107.1986 \mu \mathrm{g} / \mathrm{ml}$ menunjukkan aktivitas antioksidan yang sedang.

\section{Saran}

Disarankan pada peneliti selanjutnya untuk melakukan analisa lebih lanjut seperti GCMS, Spektroskopi ${ }^{1} \mathrm{H}-\mathrm{NMR}$, dan ${ }^{13} \mathrm{C}$-NMR, untuk dapat memastikan struktur lengkap senyawa yang telah diisolasi disertai dengan uji aktivitas lain nya.

\section{DAFTAR PUSTAKA}

Aminah, N.S., Achmad, S.A., Hakim, E.H., Syah, Y.M., Juliawaty, L.D., \& Ghisalberti, E.L., 2003, Laevifonol, Diptoindonesin A, dan Ampelopsin A, Tiga Dimer Stilbenoid dari Kulit Batang Shorea seminis V. Sl. (Dipterocarpaceae). Jurnal Matematika dan Sains, 8 (1). 31-34.

Chung, L.M., Park, M.R., Chun JC., Yun S.J., 2003, Resveratrol Accumulation and Resveratrol Synthase Gene Expression in Response to Abiotic Stresses and Hormones in Peanut Plants. Plant Sci., 164, pp. 103-109.

Hakim, E. H., 2002, Oligostilbenoid dari tumbuhan Dipterocarpaceae, Buletin of the Indonesian Socienty of Natural Product Chemistry, 2: 1-19.

Hakim, E. H., Sahidin., Syah, Y.M., Juliawaty, L. D., Achmad, A. A., Lajis, N.Hj., 2007, Oligomer Resveratrol dari Kulit Batang Shorea assamica Dyer (Dipterocarpaceae) dan sitotoksitasnya, Jurnal Matematika dan Sains, September 2007, Vol. 12 No.3.

Hadi, S. \& Noviany., 2009, The Isolation of $\alpha$-viniferin, a trimerstilbene, from Shorea ovalis Blume, Submitted for publication to Modern Applied Sciences, Canada.

Haryoto S., Hakim, E. H., Syah, Y.M., Achmad, S. A., Juliawaty, L.D., \& Latip, J., 2006, Trimerstilbenoid dari Kulit Batang Shorea Rugosa. Bull. Soc. Nat. Prod. Chem. (Indonesia), 6: $7-11$

Irwanto, 2007, Analisis Vegetasi untuk Pengolahan Kawasan Hutan Lindung Pulau Marsegu, Kabupaten Seram Bagian Barat, Provinsi Maluku. Tesis Universitas Gajah Mada, Yogyakarta.

Ismarti, 2011, Isolasi Triterpenoid Dan Uji Antioksidan Dari Fraksi Etil Asetat Kulit Batang Meranti Merah (Shorea singkawang (Miq). Artikel Pascasarjana Universitas Andalas, Padang.
Kusuma, R., 2012, Analisis Ekstrak Kulit Kayu Meranti Merah (Shorea leprosula Miq.) Sebagai Bahan Antibakteri Terhadap Bakteri Escherichia coli, Skripsi FMIPA Universitas Mulawarman, Samarinda.

Lenny, S., 2006, Senyawa Terpenoida Dan Steroida Karya Ilmiah, Departemen Kimia FMIPA Universitas Sumatera Utara, Medan.

Nazri, N.A.A., Ahmat, N., Adnan, A., Mohamad, S.A.S., and Ruzaina, S.A.S. 2011. In vitro antibacterial and radical scavenging activities of Malaysia table salad. African Journal of Biotechnology Vol. 10(30), 5728-5735.

Norhayati, M., Laily, B. Din., Sahidin, I., Siti, F.H., Nazlina, I., Zuriati, Z., \& Wan, A. Y., 2012, Acuminatol and Other Antiokxidative Resveratrol Oligomers From The Stem Bark Shorea acuminate, Article Molecules 2012, 17, 9043-9055

Radji,M.2011, Buku Ajaran Mikrobiologi, Penerbit Buku Kedokteran, Jakarta.

Rustaman, Abdurahman, M., dan Jamaludin, A., 2006, Skrinning Fitokimia Tumbuhan di Kawasan Gunung Kuda Kabupaten Bandung sebagai Penelaahan Keanekaragaman Hayati, Lembaga Penelitian Universitas Pandjajaran, Bandung.

Sari, A.B., 2016, Isolasi Dan Uji Aktivitas Antioksidan Ekstrak Methanol Kulit Batang Meranti Tembaga (Shorea leprosula Miq), Skripsi, Sekolah Tinggi Ilmu Farmasi Riau, Pekanbaru.

Saroyobudiyono, H., Hakim, E.H., Juliawaty, Syah, Y.M., Achmad, S.A., Latip, J., Said, I.M., 2008, Oligostilbenoids from Shorea gibbosa and their cytotoxic properties agains $P-388$ cells. J. Nat Med. 62. 195-198. 